\title{
Human Rhinoviruses in Korean with Acute Low Respiratory Tract Infections
}

\author{
Sanghun Park ${ }^{*}$, Sungsun Choi1, Jungim Jang1, Eunjeung Kim¹, Seokju Cho', Jihun Jung1, \\ Kyungsik Kim1, Sungkyu Park1, Musang Kim1, Yeonsun Kim², Younghee Oh'1, Kweon Jung1 \\ ${ }^{1}$ Seoul Metropolitan Government Research Institute of Public Health and Environment, Infectious Disease \\ Research Division, Gwacheon-si, Korea \\ ${ }^{2}$ Department of Public Health, Graduate School, Dankook University, Seoul, Korea \\ Email: "sanghun93@seoul.go.kr
}

Received 16 November 2015; accepted 20 December 2015; published 23 December 2015

Copyright (C) 2015 by authors and Scientific Research Publishing Inc.

This work is licensed under the Creative Commons Attribution International License (CC BY).

http://creativecommons.org/licenses/by/4.0/

c) (i) Open Access

\section{Abstract}

Human rhinovirus (HRV) must be viewed as a significant etiological agent of acute low respiratory tract infections (ALRIs) in infants and young children. The present study has been carried out to investigate the prevalence of recently identified respiratory viruses and determine the phylogenetic composition of HRV strains. In total, 923 nasopharyngeal aspirates (NPAs) collected from hospitalized patients with ALRIs between January and December 2010 (453 females and 470 males) at five referral hospitals in Seoul were tested for respiratory viruses. Viruses were detected by RT-PCR (Reverse transcription polymerase chain reaction) in $501(54.3 \%)$ of the 923 positive samples obtained. Overall, HRV was detected in $7.9 \%$, ADV in $10.2 \%$, IFV in $21.9 \%$, RSV in $3.6 \%$, hMPV in $2.7 \%, \mathrm{HCoV}$ in $2.5 \%, \mathrm{HEV}$ in $1.6 \%, \mathrm{HBoV}$ in $1.6 \%$, and PIV in $2.4 \%$ of the samples. HRV infections occurred throughout the year, with peaks in January, May, July, and November of 2010. Phylogenetic analyses using the VP4/VP2 cording region showed that among the 27 isolates with HRV, $14(52 \%)$ were infected with species A, 2 (7\%) were infected with species $B$, and 11 $\mathbf{6 1 \% )}$ were infected with the strains from HRV-C. HRV-C sequences are genetically distinct, sharing only $32 \%$ to $33 \%$ of their amino acids with HRV-A and HRV-B, while retaining $46 \%$ to $100 \%$ identity with each other. HRV-A, B, and C were co-circulating in children hospitalized with ALRIs in Korea in 2010. These findings indicated that HRV-C was the important causative agent of HRV associated with ALRIs.

\section{Keywords}

NPAs, ALRIs, Human Rhinovirus

\footnotetext{
${ }^{*}$ Corresponding author.
}

How to cite this paper: Park, S., Choi, S., Jang, J., Kim, E., Cho, S., Jung, J., Kim, K., Park, S., Kim, M., Kim, Y., Oh, Y. and Jung, K. (2015) Human Rhinoviruses in Korean with Acute Low Respiratory Tract Infections. Open Journal of Medical Microbiology, 5, 237-245. http://dx.doi.org/10.4236/ojmm.2015.54029 


\section{Introduction}

Human rhinoviruses (HRVs) are important human respiratory viruses and the most common etiological agents of upper respiratory tract infections (URTIs), lower respiratory tract infection (LRTIs) and common colds [1]-[5]. Lower respiratory illnesses are more likely to occur in specific high risk groups, including infants, and children and adults with asthma [6].

HRV is transmitted either by direct contact with contaminated fomites followed by self-inoculation of the eye or nose or by aerosolized droplets [7].

More than 100 HRV serotypes have been identified. Traditionally, HRVs have been divided into two strains: HRV-A and HRV-B. Considerable variation may exist in the genetic characteristics of different HRV strains, and the viruses seem to circulate without any identifiable pattern [8]. Phylogenetic analysis of VP4/VP2 and VP1 sequences has shown that all but one HRV serotype belonged to two different species, HRV-A (comprising 74 serotypes) and HRV-B (comprising 25 serotypes) [4] [9].

The aim of this study was to present the detection of common respiratory pathogens in respiratory illness, and to determine the frequency and genetic diversity of HRV infections during 2010 in patients between 42 days and 64 years of age, who were hospitalized with ALRIs in five reference hospitals in Seoul, Korea.

\section{Materials and Methods}

\subsection{Specimens}

In total, 923 nasopharyngeal aspirates (NPAs) collected from hospitalized patients with acute respiratory symptoms (ARS) between January and December 2010 (453 females and 470 males) at five referral hospitals in Seoul were tested for respiratory viruses. The study protocol was approved by the ethics committee of each hospital. The ages of the patients were between 42 days and 64 years, and all were patients who had presented themselves to reference hospitals in Seoul, Korea.

\subsection{Detection of Other Respiratory Viruses}

All specimens were tested for the presence of Human metapneumovirus (hMPV), respiratory syncytial virus (RSV), influenza viruses A and B (IFVA and IFVB, respectively), parainfluenza virus types 1 to 3 (PIV-1 to -3, respectively), and human coronavirus (HCoV; strains 229E, OC43), which were detected by reverse transcription-PCR, and adenovirus (ADV) and human bocavirus (HBoV), which were detected by PCR and RT-PCR , as described in a previous study [10].

\subsection{RNA Isolation and RT-PCR}

Nasal/throat swabs were each deposited into a viral transport medium (Beckton-Dickinson). After thorough mixing, each sample suspension was centrifuged $\left(800 \times \mathrm{g}, 20 \mathrm{~min}, 4^{\circ} \mathrm{C}\right)$. Nucleic acid was extracted from $200 \mu \mathrm{l}$ of sample suspension using the QIAamp Viral RNA mini kit (Qiagen, Hilden, Germany) according to the manufacturer's instructions. The viral RNA was finally eluted from the spin column in $50 \mu 1$ of elution buffer and stored at $-70^{\circ} \mathrm{C}$. RT-PCR was performed for the amplification of the 5 ' noncoding region of HRV from clinical specimens. The primer was used to amplify a 380-bp fragment of OL27 (5'-AGG ACA CCC AAA GTA G-3') and OL26 (5'-GCA CTT CTG TTT CCC C-3'). RT steps were carried out at $42^{\circ} \mathrm{C}$ for $1 \mathrm{~h}$, followed by heating at $95^{\circ} \mathrm{C}$ for $5 \mathrm{~min}$ to inactivate the enzyme, and then cooled immediately to $4^{\circ} \mathrm{C}$. Amplification reactions were subjected to an initial denaturation step of $95^{\circ} \mathrm{C}$ for $8 \mathrm{~min}$, followed by 35 amplification cycles of 45 sec at $95^{\circ} \mathrm{C}$, $45 \mathrm{sec}$ at $60^{\circ} \mathrm{C}$, and $45 \mathrm{sec}$ at $72^{\circ} \mathrm{C}$, and followed by a final extension at $72^{\circ} \mathrm{C}$ for $10 \mathrm{~min}$. All PCR amplifications were carried out on a TGRADIENT thermal cycler (Biometra, Germany).

The amplification and sequencing of the VP4/VP2 cording region is used to define genotypes. The reverse transcription (RT) was performed using a random primer. $5 \mu$ l of extracted RNA was mixed with a reaction mixture consisting of $2 \mu \mathrm{l}$ of $10 \times$ reverse transcription Buffer (Invitrogen, USA), $2 \mu 11$ of $10 \mathrm{mM}$ dNTPs (Invitrogen, USA), $1.0 \mu \mathrm{l}(1 \mu \mathrm{g} / \mu \mathrm{l})$ of 9 mer random primer (Takara, Japan), $0.75 \mu \mathrm{l}$ of $10 \mathrm{mM}$ DTT (Invitrogen), 0.5 $\mu \mathrm{l}(33 \mathrm{U} / \mu \mathrm{l})$ of RNase Inhibitor (Toyobo, Osaka, Japan), and $0.75 \mu \mathrm{l}(200 \mathrm{U} / \mu \mathrm{l})$ of SuperScript Reverse Transcriptase II (SS RTII; Invitrogen). RT steps were carried out at $42^{\circ} \mathrm{C}$ for $1 \mathrm{~h}$, followed by heating at $95^{\circ} \mathrm{C}$ for 5 min to inactivate the enzyme, and then cooled immediately to $4^{\circ} \mathrm{C}$. 
PCR and Nested PCR were carried out as described in the previous study [10]. In this study, the cDNA was then amplified in a nested PCR, using RV-1 (5'-ACCRACTACTTTGGGTGTCCGTGT-3', position 533 - 556 in HRV-C 024) as the outer sense primer, RV-2 (5'-TCIGGIADYTTCCAICACCAICC-3', position 1046 - 1067 in HRV-C 024) as the outer and inner anti sense primers for PCR, and RV-3 (5'-ACTACTTTGGGTGTC CGT-3', position 551 - 567 in HRV-C 024) as the inner sense primer for nested PCR. Both amplification reactions were subjected to an initial denaturation step of $95^{\circ} \mathrm{C}$ for $4 \mathrm{~min}$, followed by 30 amplification cycles of $30 \mathrm{sec}$ at $95^{\circ} \mathrm{C}$, $30 \mathrm{sec}$ at $60^{\circ} \mathrm{C}$, and $90 \mathrm{sec}$ at $72^{\circ} \mathrm{C}$ and followed by a final extension at $72^{\circ} \mathrm{C}$ for $10 \mathrm{~min}$. All PCR amplifications were carried out on a TGRADIENT thermal cycler (Biometra, Germany).

\subsection{Nucleotide Sequencing}

The RT-PCR products were purified using a QIAquick Gel Extraction Kit (Qiagen, Hilden, Germany). Analyses of the nucleotide sequences were carried out by Cosmogentec (Korea) using a Big Dye Dideoxy cycle sequencing kit and an ABI PRISM 3730XL Analyzer (Applied Biosystem, U.S.A.). HRVs detected in the year 2008 were determined using MEGA version 5.1 [11] by phylogenetic analysis of the VP4/VP2 cording region, using the Neighbor Joining algorithm with the Kimura two-parameter model of the Clustal X program. Partial sequences for the HRV strain were submitted to Genebank (JQ417862-417886).

\section{Results}

The 923 patients in whom respiratory viruses were detected, in this study were between 42 days and 68 years of age, with $50.3 \%$ (464/923) under 5 years of age (Figure 1$)$.

Viruses were detected by RT-PCR in 501 (54.3\%) of the 923 samples obtained. Overall, HRV was detected in $7.9 \%$, $\mathrm{ADV}$ in $10.2 \%$, IFV in $21.9 \%$, RSV in $3.6 \%$, hMPV in $2.7 \%$, $\mathrm{HCoV}$ in $2.5 \%$, HEV in $1.6 \%$, $\mathrm{HBoV}$ in $1.6 \%$, and PIV in $2.4 \%$ of the samples (Table 1 ).

Coinfections of respiratory viral agents were found in 24 (4.6\%) of the positive samples, in which the mixed infection with HRV were due to IFVA and ADV in 4 (0.8\%) samples, HEV in $3(0.6 \%)$ samples, and HBoV and $\mathrm{HCoV}$ in one (0.2\%) sample each (Table 1$)$.

HRV infections occurred throughout the year, with peaks in January, May, July, and November of 2010 (Figure 2).

Amplified PCR products of approximately 535 bp comprising the VP4/VP2 cording region were obtained from $27 \mathrm{HRV}$ prototype strains. The genetic characteristics of the $27 \mathrm{HRV}$ strains examined in this study along

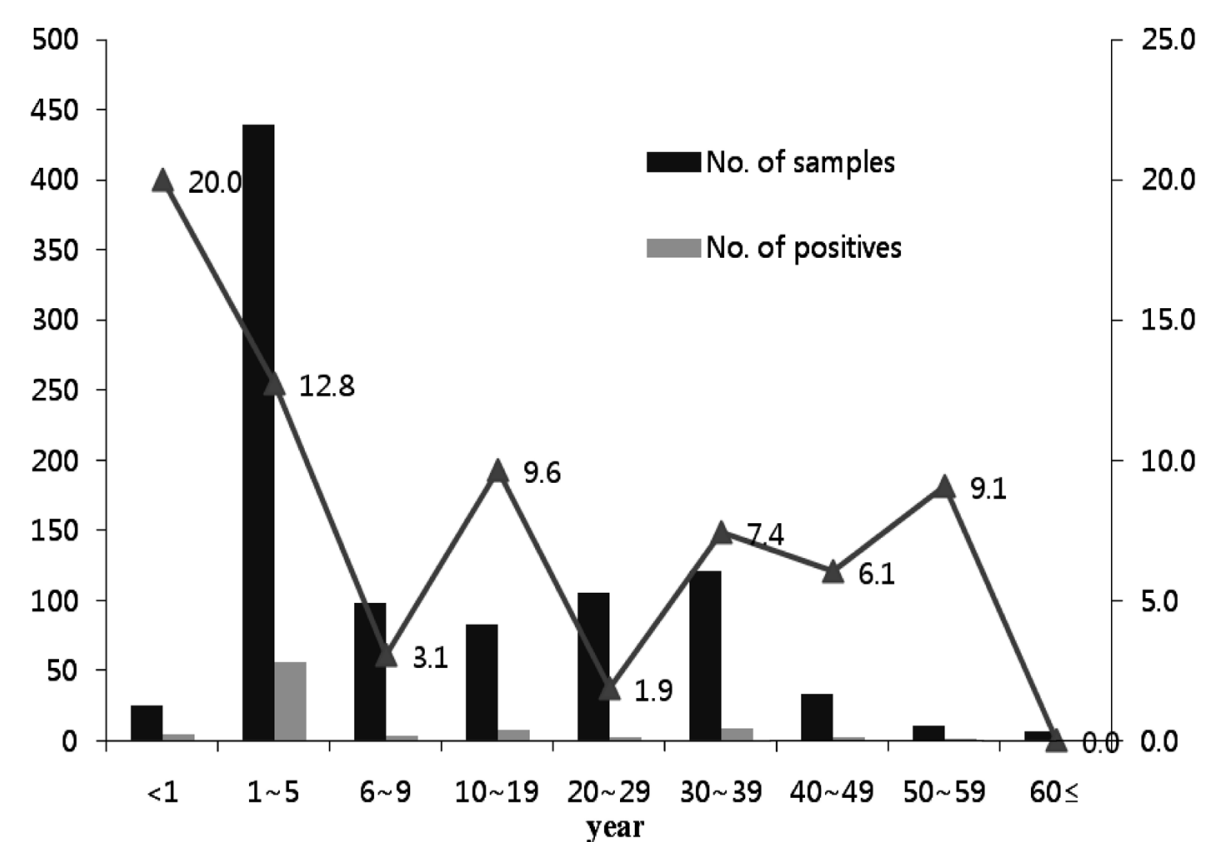

Figure 1. Distribution of the HRV-positive specimens by patient age. 


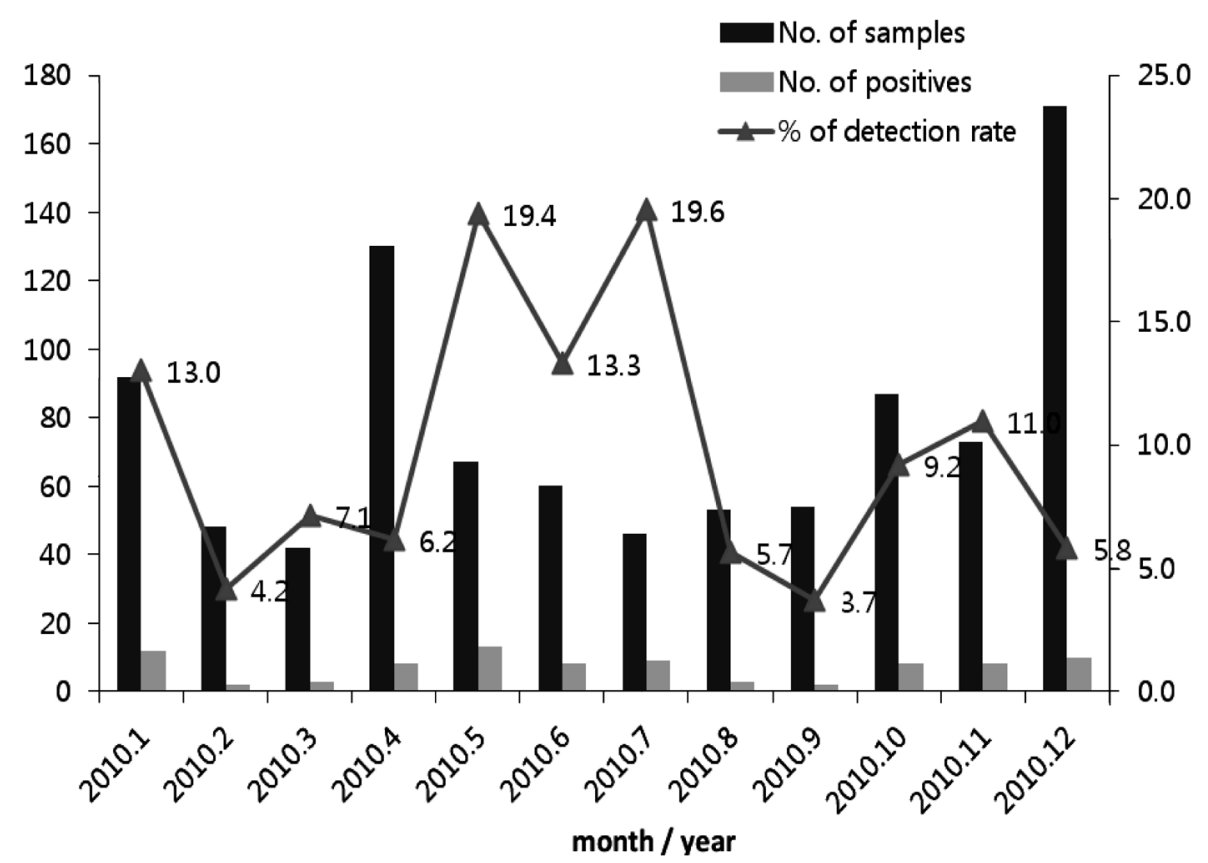

Figure 2. Monthly distribution of HRV related ALRIs in children between January 2010 to December 2010 in Seoul, Korea.

Table 1. Distribution of the different viruses in children with ALRIs with positive detections for viral infections by PCR and RT-PCR.

\begin{tabular}{ccc}
\hline Viruses & No. of positives & Detection rate (\%) \\
\hline IFVA & 121 & 13.1 \\
ADV & 94 & 10.2 \\
IFVB & 80 & 8.7 \\
HRV & 73 & 7.9 \\
RSV & 33 & 3.6 \\
hMPV & 25 & 2.7 \\
HCoV & 23 & 2.5 \\
HEV & 15 & 1.6 \\
HBoV & 15 & 1.6 \\
PIV1 & 11 & 1.2 \\
PIV3 & 11 & 1.2 \\
IFVA + HRV & 4 & 0.4 \\
ADV + HRV & 4 & 0.4 \\
HEV + HRV & 3 & 0.3 \\
ADV + RSV & 2 & 0.2 \\
HCoV + RSV & 2 & 0.2 \\
IFVB + HBoV & 2 & 0.2 \\
ADV + HCoV & 2 & 0.2 \\
HBoV + HRV & 1 & 0.1 \\
HCoV+ HRV & 1 & 0.1 \\
IFVA + HBoV & 1 & 0.1 \\
IFVA + ADV & & 0.1 \\
ADV + PIV3 & 2 & \\
\hline & 2 & 1 \\
\hline
\end{tabular}


with 21 reference strains are summarized in Figure 3.

A phylogenetic tree obtained using the NJ method based on the VP4/VP2 cording region of the viral protein

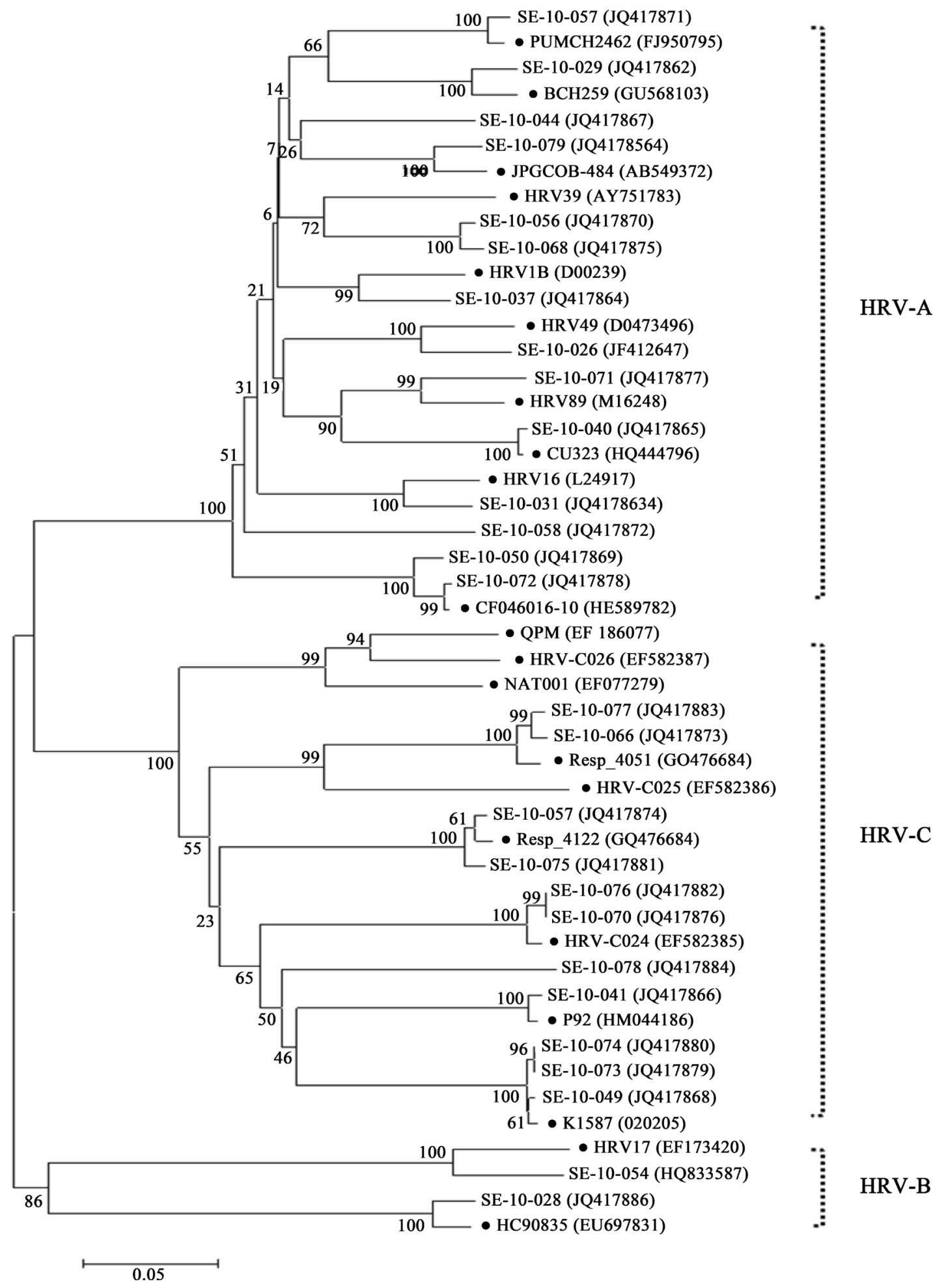

Figure 3. Phylogenetic analysis of the sequences of the VP1/P2A gene (535 bp) of the 27 HRVs with reference strains. HRV references were indicated by the dark black circle. The percentage bootstrap values were observed among the 1000 replicates indicated. GenBank accession numbers of each strain are given in parentheses. 
showed that among the 27 isolates with HRV, 14 (52\%) were infected with species A, 2 (7\%) were infected with species B, and 11 (41\%) were infected with the strains from HRV-C. The alignment of the sequences in the present study with the HRV prototype strains resulted in three clusters: HRV-A, HRV-B, and HRV-C. Within the HRV-A cluster, the between-serotype pair wise nucleotide identities ranged from $72 \%$ to $96 \%$, and the corresponding amino acid identities from $48 \%$ to $91 \%$. The corresponding values in the HRV-C species were from $69 \%$ to $100 \%$ and from $46 \%$ to $100 \%$, respectively. Between the human rhinovirus species the nucleotide and amino acid identities varied between $57 \%$ and $60 \%$, and $33 \%$ and $44 \%$, respectively.

\section{Discussion}

In order to better understand which viruses is the most common causative agent of ALRIs, it would be valuable to know the monitoring and surveillance results of well-recognized respiratory viruses.

HRV is often concurrently detected with other viruses found in the respiratory tract occurring throughout the year [12]. However, few studies in Korea have reported HRV infections. Cho et al. identified HRV in $18.5 \%$ of neonates hospitalized with ALRIs from January 2009 through to May 2010 [13]. Chung et al. detected HRV in $33.3 \%$ of children hospitalized with acute wheezing, aged from 1 month to 5 years [12].

Previous studies have indicated that HRVs are the most common cause of illness in children and adults of all ages in around world [14]-[18]. In the present study, more than half of the patients (54.3\%) were infected with at least one viral agent, with HRV being the fourth most common virus. The prevalent rates are in good agreement with other reports [19] [20]. Another study performed in Hong Kong from 2004 to 2005 also found that $16.9 \%$ were positive for HRV in NPAs (Nasopharyngeal aspirates) from pediatric patients [4]. The most prevalent age of the patients infected with HRV (were those under 5 years of age). The number of these patients was found to be significantly higher than the HRV infected patients over 5 years of age. This finding is in agreement with a recent prospective multicenter surveillance study of hospitalized children documenting HRV, which found that HRV was detected more frequently in children $<5$ years of age [21]. This was in line with the observation that young children with respiratory symptoms have a major role in the transmission of HRV [22] [23]. Another study performed in the Canada between 1999 and 2000 found that HRVs are often the most prevalent virus detected in children with acute respiratory disease [24]. More remarkably, another study performed in Greece from 1988 to 1990 reported that the presence of HRV increased the risk for disease severity in acute bronchiolitis by approximately fivefold [14]. The seasonal distribution of HRV infections showed that it was detected throughout the year, with peaks in spring and autumn in temperate regions [8], which was also confirmed by other studies [21] [25] [26]. The HRV species in our study was detected predominately in the spring and summer. Interestingly, our study has demonstrated that HRV infections occur year round.

Some investigators have indicated that co-infection with different respiratory viruses might lead to a more severe disease, or have found that multiple viruses have been detected from patients with severe disease [27]-[29]. The present results showed that combinations of respiratory virus infections were present in 24 (4.6\%) of the positive samples, in which the most common mixed infection was IFVA, ADV, and HRV in $4(0.8 \%)$ of the positive samples. Previous studies have indicated that the co-infection rates were 2.3\% [30], 4.5\% [31], and, $23 \%$ [32]. This is in contrast to a respiratory virus infection study like ours, in which the mixed respiratory virus infections found that the main viral agents detected were RSV (36 of 44) and HRV (22 of 44), these two viral agents resulted in the most found dual viral respiratory infections (29.5\%), and co-infections occurred in about half of the children [33] [34]. Another study showed that RSV and HCoV were the major co-infection viruses. The reason is partly due to the high detection rate of RSV and the similar seasonal circulation patterns of these viruses [19]. Our observations are also consistent with the findings of Greer et al. [12] who identified similar negative associations between the detection of HRV and the co-detection of different respiratory viruses, including IFVA [35].

The detection rates for the three HRV species, HRV-A, HRV-B, and HRV-C, were 52\%, 7\%, and 41\%, respectively. This pattern is in agreement with previous report on molecular epidemiology of human rhinovirus infection in Mongolian 2008-2013 in which its prevalence was shown in HRV-A, HRV-B, and HRV-C, were 47.1\%, 8.2\%, and 44.7\%, respectively [20]. As reported from other parts of the world, HRV-A and HRV-C were found to be the also predominant as it was identified in 34\% - 63\% of tested samples, whereas HRV-B was the least common species [5] [20]. A previous report indicated that 5\% of RTIs among inpatients are caused by HRV-C [36]. It has been reported that investigators have detected the newly described HRV-C in several countries [14]. HRV-C appears to be an important cause of febrile wheeze and asthmatic exacerbation in children 
requiring hospitalization [4]. Complete genome analysis reveals that HRV-C is circulating worldwide and is associated with acute respiratory infections [4]. In our study, 11 of $27 \mathrm{HRV}$ sequences (41\%) were grouped in the HRV-C cluster. It has been suggested by Jin et al. that HRV-C is an important etiological factor in children with RTIs [19].

In this study, the HRV-C sequences are genetically distinct, sharing only $32 \%$ to $33 \%$ of their amino acids with HRV-A and HRV-B, while retaining $46 \%$ to $100 \%$ identity with each other. In addition, these sequences showed 51\% to 59\% amino acid identity with known strains of HRV QPM. In accordance with previous data, HRV-C showed a high degree of sequence variation between individual strains [19]. A recent studies investigated HRV-C may be more frequently associated with LRTI compared to HRV-A, even when adjusting for confounding factors [3] [37]. It is important to carefully monitor the species to be prepared for the potential emergence of more virulent variants.

\section{Conclusion}

The aim of this study was to present the detection of common respiratory pathogens in respiratory illness, and to investigate and describe the molecular epidemiology of HRV circulating in Seoul, Korea. In conclusion, HRV-A, B, and C were co-circulating in children hospitalized with ALRIs in Korea in 2010. These findings indicated that HRV-C was the important causative agent of HRV associated with ALRIs.

\section{References}

[1] Calvo, C., García-García, M.L., Blanco, C., Pozo, F., Flecha, I.C. and Pérez-Breña, P. (2007) Role of Rhinovirus in Hospitalized Infants with Respiratory Tract Infections in Spain. The Pediatric Infectious Disease Journal, 26, 904-908. http://dx.doi.org/10.1097/INF.0b013e31812e52e6

[2] Camps Serra, M., Cervera, C., Pumarola, T., Moreno, A., Perelló, R., Torres, A., Jiménez de Anta, M.T. and Marcos, M.A. (2008) Virological Diagnosis in Community-Acquired Pneumonia in Immunocompromised Patients. European Respiratory Journal, 31, 618-624. http://dx.doi.org/10.1183/09031936.00073807

[3] Johnstone, J., Majumdar, S.R., Fox, J.D. and Marrie, T.J. (2008) Viral Infection in Adults Hospitalized with Community-Acquired Pneumonia: Prevalence, Pathogens, and Presentation. Chest, 134, 1141-1148. http://dx.doi.org/10.1378/chest.08-0888

[4] Lau, S.K., Yip, C.C., Tsoi, H.W., Lee, R.A., So, L.Y., Lau, Y.L., Chan, K.H., Woo, P.C. and Yuen, K.Y. (2007) Clinical Features and Complete Genome Characterization of a Distinct Human Rhinovirus (HRV) Genetic Cluster, Probably Representing a Previously Undetected HRV Species, HRV-C, Associated with Acute Respiratory Illness in Children. Journal of Clinical Microbiology, 45, 3655-3664. http://dx.doi.org/10.1128/JCM.01254-07

[5] Martin, E.K., Kuypers, J., Chu, H.Y., Lacombe, K., Qin, X., Strelitz, B., Bradford, M., Jones, C., Klein, E.J. and Englund, J.A. (2015) Molecular Epidemiology of Human Rhinovirus Infections in the Pediatric Emergency Department. Journal of Clinical Virology, 62, 25-31. http://dx.doi.org/10.1016/j.jcv.2014.11.006

[6] Kim, W.K. and Gern, J.E. (2012) Updates in the Relationship between Human Rhinovirus and Asthma. Allergy, Asthma \& Immunology Research, 4, 116-121. http://dx.doi.org/10.4168/aair.2012.4.3.116

[7] Myatt, T.A., Johnston, S.L., Zuo, Z., Wand, M., Kebadze, T., Rudnick, S. and Milton, D.K. (2004) Detection of Airborne Rhinovirus and Its Relation to Outdoor Air Supply in Office Environments. American Journal of Respiratory and Critical Care Medicine, 169, 1187-1190. http://dx.doi.org/10.1164/rccm.200306-760OC

[8] Mackay, I.M. (2008) Human Rhinoviruses: The Cold Wars Resume. Journal of Clinical Virology, 42, $297-320$. http://dx.doi.org/10.1016/j.jcv.2008.04.002

[9] Turner, R.B. and Couch, R.B. (2007) Rhinoviruses. In: Knipe, D.M. and Howley, P.M., Eds., Fields Virology, Lippincott, Williams \& Wilkins Publishing, Philadelphia, 895-909.

[10] Chung, J.Y., Han, T.H., Kim, S.W., Kim, C.K. and Hwang, E.S. (2007) Detection of Viruses Identified Recently in Children with Acute Wheezing. Journal of Medical Virology, 79, 1238-1243. http://dx.doi.org/10.1002/jmv.20926

[11] Tamura, K., Peterson, D., Peterson, N., Stecher, G., Nei, M. and Kumar, S. (2011) MEGA5: Molecular Evolutionary Genetics Analysis Using Maximum Likelihood, Evolutionary Distance, and Maximum Parsimony Methods. Molecular Biology and Evolution, 28, 2731-2739. http://dx.doi.org/10.1093/molbev/msr121

[12] Greer, R.M., McErlean, P., Arden, K.E., Faux, C.E., Nitsche, A., Lambert, S.B., Nissen, M.D., Sloots, T.P. and Mackay, I.M. (2009) Do Rhinoviruses Reduce the Probability of Viral Co-Detection during Acute Respiratory Tract Infections? Journal of Clinical Virology, 45, 10-15. http://dx.doi.org/10.1016/j.jcv.2009.03.008

[13] Cho, H.J., Shim, S.Y., Son, D.W., Sun, Y.H., Tchah, H. and Jeon, I.S. (2012) Respiratory Viruses in Neonates Hospi- 
talized with Acute Lower Respiratory Tract Infections. Pediatrics International, 55, 49-53. http://dx.doi.org/10.1111/j.1442-200X.2012.03727.x

[14] Papadopoulos, N.G., Moustaki, M., Tsolia, M., Bossios, A., Astra, E., Prezerakou, A., Gourgiotis, D. and Kafetzis, D. (2002) Association of Rhinovirus Infection with Increased Disease Severity in Acute Bronchiolitis. American Journal of Respiratory and Critical Care Medicine, 165, 1285-1289. http://dx.doi.org/10.1164/rccm.200112-118BC

[15] Arden, K.E., McErlean, P., Nissen, M.D., Sloots, T.P. and Mackay, I.M. (2006) Frequent Detection of Human Rhinoviruses, Paramyxoviruses, Coronaviruses, and Bocavirus during Acute Respiratory Tract Infections. Journal of Medical Virology, 78, 1232-1240. http://dx.doi.org/10.1002/jmv.20689

[16] Winther, B., Hayden, F.G. and Hendley, J.O. (2006) Picornavirus Infections in Children Diagnosed by RT-PCR during Longitudinal Surveillance with Weekly Sampling: Association with Symptomatic Illness and Effect of Season. Journal of Medical Virology, 78, 644-650. http://dx.doi.org/10.1002/jmv.20588

[17] Taipale, A., Pelkonen, T., Roivainen, M., Kaijalainen, S., Bernardino, L., Peltola, H. and Pitkäranta, A. (2014) Human Rhino- and Enteroviruses in Children with Respiratory Symptoms in Luanda, Angola. Paediatrics and International Child Health, 34, 128-132. http://dx.doi.org/10.1179/2046905513Y.0000000101

[18] Bender, J.M., Taylor, C.S., Cumpio, J., Novak, S.M., She, R.C., Steinberg, E.A. and Marlowe, E.M. (2014) Infants 1-90 Days Old Hospitalized with Human Rhinovirus Infection. Journal of Clinical Laboratory Analysis, 28, 349-352. http://dx.doi.org/10.1002/jcla.21692

[19] Jin, Y., Yuan, X.H., Xie, Z.P., Gao, H.C., Song, J.R., Zhang, R.F., Xu, Z.Q., Zheng, L.S., Hou, Y.D. and Duan, Z.J. (2009) Prevalence and Clinical Characterization of a Newly Identified Human Rhinovirus C Species in Children with Acute Respiratory Tract Infections. Journal of Clinical Microbiology, 47, 2895-2900. http://dx.doi.org/10.1128/JCM.00745-09

[20] Tsatsral, S., Xiang, Z., Fuji, N., Maitsetseg, C., Khulan, J., Oshitani, H., Wang, J. and Nymadawa, P. (2015) Molecular Epidemiology of Human Rhinovirus Infection in Mongolian 2008-2013. Japanese Journal of Infectious Diseases, 68, 280-287. http://dx.doi.org/10.7883/yoken.JJID.2014.090

[21] Miller, E.K., Lu, X., Erdman, D.D., Poehling, K.A., Zhu, Y., Griffin, M.R., Hartert, T.V., Anderson, L.J., Weinberg, G.A., Hall, C.B., Iwane, M.K. and Edwards, K.M. (2007) Rhinovirus-Associated Hospitalizations in Young Children. Journal of Infectious Diseases, 195, 773-781. http://dx.doi.org/10.1086/511821

[22] Peltola, V. and Ruuskanen, O. (2008) Editorial Commentary: Respiratory Viral Infections in Developing Countries: Common, Severe, and Unrecognized. Clinical Infectious Diseases, 46, 58-60. http://dx.doi.org/10.1086/524020

[23] Peltola, V., Waris, M., Osterback, R., Susi, P., Hyypiä, T. and Ruuskanen, O. (2008) Clinical Effects of Rhinovirus Infections. Journal of Clinical Virology, 43, 411-414. http://dx.doi.org/10.1016/j.jcv.2008.08.014

[24] Fox, J.D. (2007) Respiratory Virus Surveillance and Outbreak Investigation. Journal of Clinical Virology, 40, S24S30. http://dx.doi.org/10.1016/S1386-6532(07)70006-9

[25] Monto, A.S. (2004) Occurrence of Respiratory Virus: Time, Place and Person. Pediatric Infectious Disease Journal, 23, S58-S64. http://dx.doi.org/10.1097/01.inf.0000108193.91607.34

[26] Arruda, E., Pitkäranta, A., Witek, T.J. and Doyle, C.A. (1997) Frequency and Natural History of Rhinovirus Infections in Adults during Autumn. Journal of Clinical Microbiology, 35, 2864-2868.

[27] Bharaj, P., Sullender, W.M., Kabra, S.K., Mani, K., Cherian, J., Tyagi, V., Chahar, H.S., Kaushik, S., Dar, L. and Broor, S. (2009) Respiratory Viral Infections Detected by Multiplex PCR among Pediatric Patients with Lower Respiratory Tract Infections Seen at an Urban Hospital in Delhi from 2005 to 2007. Virology Journal, 6, 89. http://dx.doi.org/10.1186/1743-422X-6-89

[28] Kaida, A., Kubo, H., Goto, K., Shiomi, M., Kohdera, U. and Iritani, N. (2007) Co-Infection of Human Metapneumovirus with Adenovirus or Respiratory Syncytial Virus among Children in Japan. Microbiology and Immunology, 51, 679683. http://dx.doi.org/10.1111/j.1348-0421.2007.tb03956.x

[29] McErlean, P., Shackelton, L.A., Lambert, S.B., Nissen, M.D., Sloots, T.P. and Mackay, I.M. (2007) Characterisation of a Newly Identified Human Rhinovirus, HRV-QPM, Discovered in Infants with Bronchiolitis. Journal of Clinical Virology, 39, 67-75. http://dx.doi.org/10.1016/j.jcv.2007.03.012

[30] Templeton, K.E., Scheltinga, S.A., Beersma, M.F., Kroes, A.C. and Claas, E.C. (2004) Rapid and Sensitive Method Using Multiplex Real-Time PCR for Diagnosis of Infections by Influenza A and Influenza B Viruses, Respiratory Syncytial Virus, and Parainfluenza Viruses 1, 2, 3, and 4. Journal of Clinical Microbiology, 42, 1564-1569. http://dx.doi.org/10.1128/JCM.42.4.1564-1569.2004

[31] Coiras, M.T., Pérez-Breña, P., García, M.L. and Casas, I. (2003) Simultaneous Detection of Influenza A, B, and C Viruses, Respiratory Syncytial Virus, and Adenoviruses in Clinical Samples by Multiplex Reverse Transcription NestedPCR Assay. Journal of Medical Virology, 69, 132-144. http://dx.doi.org/10.1002/jmv.10255

[32] Bellau-Pujol, S., Vabret, A., Legrand, L., Dina, J., Gouarin, S., Petitjean-Lecherbonnier, J., Pozzetto, B., Ginevra, C. 
and Freymuth, F. (2005) Development of Three Multiplex RT-PCR Assays for the Detection of 12 Respiratory RNA Viruses. Journal of Virological Methods, 126, 53-63. http://dx.doi.org/10.1016/j.jviromet.2005.01.020

[33] Paranhos-Baccalà, G., Komurian-Pradel, F., Richard, N., Vernet, G., Lina, B. and Floret, D. (2008) Mixed Respiratory Virus Infections. Journal of Clinical Virology, 43, 407-410. http://dx.doi.org/10.1016/j.jcv.2008.08.010

[34] Meerhoff, T.J., Houben, M.L., Coenjaerts, F.E., Kimpen, J.L., Hofland, R.W., Schellevis, F. and Bont, L.J. (2010) Detection of Multiple Respiratory Pathogens during Primary Respiratory Infection: Nasal Swab versus Nasopharyngeal Aspirate Using Real-Time Polymerase Chain Reaction. European Journal of Clinical Microbiology \& Infectious Diseases, 29, 365-371. http://dx.doi.org/10.1007/s10096-009-0865-7

[35] Casalegno, J.S., Ottmann, M., Duchamp, M.B., Escuret, V., Billaud, G., Frobert, E., Morfin, F. and Lina, B. (2010) Rhinoviruses Delayed the Circulation of the Pandemic Influenza A (H1N1) 2009 Virus in France. Clinical Microbiology and Infection, 16, 326-329. http://dx.doi.org/10.1111/j.1469-0691.2010.03167.x

[36] Briese, T., Renwick, N., Venter, M., Jarman, R.G., Ghosh, D., Köndgen, S., Shrestha, S.K., Hoegh, A.M., Casas, I., Adjogoua, E.V., Akoua-Koffi, C., Myint, K.S., Williams, D.T., Chidlow, G., van den Berg, R., Calvo, C., Koch, O., Palacios, G., Kapoor, V., Villari, J., Dominguez, S.R., Holmes, K.V., Harnett, G., Smith, D., Mackenzie, J.S., Ellerbrok, H., Schweiger, B., Schønning, K., Chadha, M.S., Leendertz, F.H., Mishra, A.C., Gibbons, R.V., Holmes, E.C. and Lipkin, W.I. (2008) Global Distribution of Novel Rhinovirus Genotype. Emerging Infectious Diseases, 14, 944947. http://dx.doi.org/10.3201/eid1406.080271

[37] Linder, J.E., Kraft, D.C., Mohamed, Y., Lu, Z., Heil, L., Tollefson, S., Saville, B.R., Wright, P.F., Williams, J.V. and Miller, E.K. (2014) Human Rhinovirus C: Age, Season, and Lower Respiratory Illness over the Past 3 Decades. Journal of Allergy and Clinical Immunology, 131, 69-77. http://dx.doi.org/10.1016/j.jaci.2012.09.033

\section{Abbreviations}

ALRIs = acute low respiratory tract infections;

ARS = acute respiratory symptoms;

$\mathrm{ADV}=$ adenovirus;

$\mathrm{HBoV}=$ human bocavirus;

$\mathrm{HCoV}=$ human coronavirus;

hMPV = human metapneumovirus;

HRV = human rhinovirus;

IFVA = influenza viruses A;

IFVB = influenza viruses B;

NPAs = nasopharyngeal aspirates;

PIV-1 = parainfluenza virus types 1 ;

PIV-2 = parainfluenza virus types 2 ;

PIV-3 = parainfluenza virus types 3 ;

RSV = respiratory syncytial virus;

URTIs = upper respiratory tract infections. 